\title{
Balıkesir ve Çanakkale İllerinde Buğday Ürünü İçerisine Karışan Yabancı Ot Tohumlarının
} Belirlenmesi

\author{
Koray KAÇAN ${ }^{1}$ iD, Nihat TURSUN ${ }^{\infty}$ (iD \\ ${ }^{1}$ Muğla Sitkı Koçman Üniversitesi, Ortaca MYO, Muğla, ${ }^{2}$ Malatya Turgut Özal Üniv. Ziraat Fakültesi, Bitki Koruma Bölümü, Malatya \\ ${ }^{1}$ https://orcid.org/0000-0003-3316-9286, ${ }^{2}$ https://orcid.org/0000-0002-8765-0326 \\ $\bowtie$ : nihat.tursun@ozal.edu.tr
}

\section{ÖZET}

Araştırma 2015 yılında Balıkesir ve Çanakkale illerinde buğday ürününe karışan yabancı ot tohumlarının tür ve miktarlarını belirlemek amacıyla 93 farklı yerden alınan $1 \mathrm{~kg}$ 'lı örneklerle yürütülmüştür. Çalışma sonunda $1 \mathrm{~kg}$ ürüne ortalama, Balıkesir il genelinde 207 adet, ağırlık olarak ise $3.06 \mathrm{~g}$ yabancı ot tohumunun karıştığı, Çanakkale il genelinde ise 181 adet ve $2.98 \mathrm{~g}$ yabancı ot tohumu karıştığı hesaplanmıştır. Her iki ilde de buğday ürünü içerisine 15 familyaya ait 45 farklı yabancı ot tohumunun karıştığı belirlenmiştir. Balıkesir il genelinde sayısal olarak en fazla karışan yabanc1 ot tohumunun Sinapis arvensis L. (77.,53 adet $/ \mathrm{kg})$ olduğu belirlenirken, ağırlık olarak ise Hordeum vulgare $\mathrm{L} .(0.7034 \mathrm{~g} / \mathrm{kg})$ olduğu saptanmıştır. Çanakkale il genelinde buğday ürününe karışan yabancı ot tohumları incelendiğinde; sayısal olarak Galium aparine L. hin (35.18 adet $/ \mathrm{kg})$ en fazla karışan yabancı ot olduğu, ağırlık olarak ise $H$. vulgare $(0.558 \mathrm{~g} / \mathrm{kg})$ en fazla buğday ürününe karışan yabancı ot olduğu bulunmuştur.

\section{Determination of Weed Seeds Mixed to Wheat Grains in Balıkesir and Çanakkale Provicens}

\section{ABSTRACT}

The research was conducted in 2015 with wheat samples (1 kg each) taken from 93 different locations in order to determine the species and amount of weed seeds in the samples in Balıkesir and Canakkale provinces. At the end of the study, it was determined that an average of 207 weed seeds with a weight of $3.06 \mathrm{gr}$ was found in a $1 \mathrm{~kg}$ of wheat product in Balıkesir province. In the province of Çanakkale, it was found that an average of 180,59 weed seeds with a weight of 2,9819 gr was mixed with $1 \mathrm{~kg}$ of wheat product. overall, 45 different weed seeds belonging to 15 families were determined in wheat product. Throughout Ballkesir province, the most common weed seed found in wheat product was Sinapis arvensis L. (77.53 seeds $/ \mathrm{kg})$ in terms of number of seeds, whereas Hordeum vulgare L. $(0.7034 \mathrm{gr} / \mathrm{kg})$ was the weed seed with the largest weight. In Çanakkale province the most frequent weed seed found in wheat product was $G$. aparine (35.18 seeds $/ \mathrm{kg}$ ) followed by $S$. arvensis, In terms of weight, the most frequent weed seed found in wheat product was $H$. vulgare $(0.558$ $\mathrm{gr} / \mathrm{kg}$ ).

\section{Araştırma Makalesi}

$\begin{array}{ll}\text { Makale Tarihçesi } \\ \text { Geliş Tarihi } & : 27.11 .2018 \\ \text { Kabul Tarihi } & : 17.01 .2019\end{array}$

\section{Anahtar Kelimeler}

Buğday

Yabancı ot tohumları

Bulaşma

To Cite : Kaçan K, Tursun N 2019. Balıkesir ve Çanakkale İllerinde Buğday Ürünü İçerisine Karışan Yabancı Ot Tohumlarının Belirlenmesi. KSÜ Tarım ve Doğa Derg 22(2): 248-259. DOI: 10.18016/ksutarimdoga.vi.488510

\section{GIRIŞ̧}

Dünya'nın karşı karşıya geldiği en büyük zorluklardan biri nüfusun 2050 yılına kadar 10 milyar kişiye ulaşacak olmasıdır. Günümüze göre, 2050'de iki milyar insanın daha beslenmesi için, gida üretiminin küresel olarak \% 50 oranında artması gerekmektedir. İnsanların temel besin kaynaklarından olan buğday, günümüzde stratejik bir ürün olarak kabul edilmekte olup ekiliş ve üretim bakımından ilk sırada yer almaktadır. Bitkisel ürünler içerisinde en fazla ekiliş̧ ve üretimi olan tahıllar insan beslenmesinde kullanılan toplam kalorinin \% 52'sini ve proteinlerin ise \% 63'ünü oluşturmaktadır (Bates ve Heyne, 1980; Borlaugh, 1982). Insanlar günlük besin gereksiniminin yaklaşık 3/4'ünü tahıllardan sağlamaktadır. Tahıl danelerinin içeriği cinslere göre 
farklılık göstermekle birlikte, yaklaşık \% 65-75 nişasta, \% 8-15 protein, \% 1-5 yağ ve \% 0.5-3 şeker içermektedirler (Kün, 1988). Tahıllar, yaşaması toprağa bağlı olan insanların en temel besinleridir. Bununla birlikte dane ve saman gibi önemli bir yem kaynağını da oluştururlar (İnan ve Rehber, 1987). Türkiye'de ulusal düzeyde kalori tüketiminin \% 53'ü buğdaydan yapılan ekmek ve diğer ürünlere dayanmaktadır (Ínan ve Rehber, 1987).

2016 yılında Dünyada toplam 220.107.551 ha alanda buğday yetiştiriciliği yapılmış ve 749.460 .077 ton ürün elde edilmiştir (Anonim, 2017). Türkiye'de ise 7.609.868 ha alanda buğday ekimi yapılmış ve 20.600 .000 ton ürün elde edilirken verim $2815 \mathrm{~kg} / \mathrm{ha}$ olarak gerçekleşmiştir (Anonim, 2016). Marmara Bölgesinde yer alan Balıkesir ilinde yaklaşık 122.221 ha alanda buğday ekimi yapılmakta, 365.563 ton ürün elde edilirken, Çanakkale ilinde 78.909 ha buğday ekimin alanından 248.475 ton buğday ürünü elde edilmiştir (Anonim, 2016).

Temel besin kaynağı olan buğday üretimini ve verimini sınırlandıran sorunların içerisinde bitki koruma sorunları oldukça önemli yer tutmaktadır. Bitki koruma sorunları içerisinde hastalık ve zararlılarla mücadele yanında yabancı otlar, buğdayın besin maddesine, su ve ışığına ortak olarak, gelişmesini engelleyerek verimini düşürmektedir. Ayrıca, buğday hasadını olumsuz yönde etkilemesi sonunda kültür bitkisinin kalitesini ve kantitesini önemli oranda düşürmektedir (Tursun ve ark.,2006). Yabancı otlar su, ışık ve besin maddeleri için buğday ile rekabete girer. Yabancı otların buğdaya göre daha yüksek rekabet gücüne sahip olması yabancı ot yoğunluğuna ve türüne bağlı olarak büyük verim kayıpları oluşabilir hatta yabancı otlarla aşırı bulaşık tarlalarda ürün almak mümkün olmayabilir. Yabancı otların direkt olarak verdikleri zarar dışında; tohumları ürüne karışarak kalitenin dolayısıyla buğdayın tohumluk değerinin düşmesine, ürün içinde bulunan yabancı ot tohumları una karışarak unlu mamullerin renk, koku ve tadını bozulmasına ayrıca zehirlenmelere de neden olabilirler (Tursun ve ark.,2006). Türkiye' de yabancı otların buğdayda meydana getirdiği ürün kaybı bölgeden bölgeye değişmekle birlikte ortalama \% 20-35 arasındadır (Tepe, 1998; Uygur ve ark., 1986). Bununla birlikte yabancı otlarla mücadele yabancı otun büyüme ve gelişme dönemlerine göre, tür ve yoğunluğuna, tek yıllık ya da çok yıllık olmalarına göre ve zarar şekline bağlı olarak değişmektedir. Yabancı otların verime olumsuz etkisi yanında, kaliteye verdiği zarar da küçümsenmemelidir. Mücadele yapılacak yabancı otun yayılma yollarının iyi saptanması ve bu yolların ortadan kaldırılması mücadelede atılacak ilk adımı oluşturmaktadır. Diğer mücadele yöntemlerine nazaran kolay ve etkili olması nedeniyle öncelikle bulaşmayı önleyici tedbirlerin alınması gerekmektedir. Çünkü buğdayda yabancı otlarla mücadelede en önemli hususlardan birisi bulaşmayı önlemektir (Özer ve ark., 1998). Bu amaçla tarlaya ekilecek buğday tohumluğunun yabancı otlardan temizlenmesi gerekmektedir. Böylece, yabancı ot tohumlarının buğday tohumluğuyla tarlaya ekilmesi önlenebilir.

Türkiye'de yapılan birçok çalışmada selektörden geçirilmemiş buğdaylarda yabancı ot tohumlarının ülkemiz genelinde buğday ürününe karışma oranları sayısal olarak \% 1.17, ağırlık olarak \% 0.412 olarak saptanmıştır (Güncan ve Boyraz, 2001, Güncan, 2002). Türkiye'deki buğday üretiminin 20 milyon ton civarında olduğu kabul edilirse, buğday ürününün temizlenmemesi halinde her yll 8.240 ton yabancı ot tohumunun bulaştığı ortaya çıkmaktadır. Aynı araştırıcılar söz konusu buğdayın temizlenmeden ekilmesi halinde dekara ortalama 5.600 yabanc1 ot tohumunun sadece bulaşık buğday tohumu ile tarlaya taşınacağını belirtmektedir. Bir başka ifadeyle $\mathrm{m}^{2}$ 'ye söz konusu yolla 5-6 yabancı ot tohumu taşınmakta ve bu yolla önemli derecede yabancı ot bulaşması olabilmektedir (Bozkan, 2013). Türkiye'de yapılan diğer çalışmalarda $1 \mathrm{~kg}$ buğday ürünü içerisinde; Kahramanmaraş ilinde ortalama olarak $10.51 \mathrm{~g}$. (Tursun ve ark., 2006), Adlyaman ilinde $46.717 \mathrm{~g}$. Gaziantep ilinde 15.316 g. (Tursun ve ark.,2004), Erzurum ili genelinde \% 2.04 (Zengin, 1996), Gümüşhane ve Bayburt illerinde 23.05 g. (Baş, 2011), Tokat ili genelinde \% 0.502 (Sirma ve ark. 1997), Van ilinde \% 13,11 (Tepe, 1998), Samsun ilinde 41.2 adet (Mennan ve Doğan, 2003), Konya ilinde \% 0.9522 (Karaca ve Güncan, 2009), Mardin'de 15.16 g (Gökalp ve Üremiş, 2015), Muş ilinde 15.8 gr (Bozkurt, 2018) miktar ve oranlarda yabancı ot tohumumun karıştığı belirlenmiştir. Daha önce çalışılmamış olan Balıkesir ve Çanakkale illerinde buğday ürününe karışan yabancı ot türleri ve hangi oranda karıştığının belirlenmesi amacıyla bu çalışma yapılmıştır.

\section{MATERYAL ve YÖNTEM}

2015 yılında yapılan bu çalışmanın materyalini Balıkesir ve Çanakkale illerine bağlı merkez ve ilçelerden tesadüfi olarak alınan buğday örnekleri içerisinde bulunan yabancı ot tohumları oluşturmaktadır. Balıkesir ilinin Balya, Bigadiç, Dursunbey, Gömeç, İvrindi, Kepsut, Manyas, Merkez, Savaştepe, Sındırgı ve Susurluk, Çanakkale ilinin ise Ayvacık, Bayramiç, Biga, Çan, Eceabat, Ezine, Merkez ve Lapseki ilçelerinden toplam 93 adet 1 kg'lık buğday örnekleri alınmıştır (Çizelge 1). Balıkesir ve Çanakkale illerinden buğday örneği alınan yerler ise Şekil 1 'de gösterilmiştir. Balıkesir ve Çanakkale illerinden buğday örneklerinin alındığı yerler tesadüfi olarak seçilmiştir. Seçilen her yerden yine tesadüfi olarak 1 kg'lık örnekler selektör işleminden önce alınıp ağzı kilitli plastik torbalarda muhafaza edilmiştir. 
Çizelge 1. Balıkesir ve Çanakkale illerinde 2015 yılı buğday üretim alanı, miktarı, buğday örneği alınan ilçeler ve alınan örnek sayıları (Anonim, 2016).

\begin{tabular}{|l|c|c|c|}
\hline İl ve İlçeler & $\begin{array}{l}\text { Ekim Alanı } \\
\text { (da) }\end{array}$ & $\begin{array}{l}\text { Üretim } \\
\text { (ton) }\end{array}$ & $\begin{array}{l}\text { Örnek } \\
\text { sayısı (adet) }\end{array}$ \\
\hline Balıkesir & & & \\
\hline Balya & 31.250 & 6.552 & 5 \\
\hline Bigadiç & 111.800 & 33.774 & 5 \\
\hline Dursunbey & 73.000 & 10.387 & 6 \\
\hline Gömeç & 6.791 & 1.802 & 3 \\
\hline İvrindi & 60.000 & 10.784 & 5 \\
\hline Kepsut & 56.461 & 12.427 & 7 \\
\hline Manyas & 94.569 & 34.804 & 7 \\
\hline Merkez & 188.512 & 53.498 & 8 \\
\hline Savaştepe & 43.334 & 10.386 & 4 \\
\hline Sındırgı & 98.000 & 23.484 & 8 \\
\hline Susurluk & 101.252 & 35.945 & 5 \\
\hline TOPLAM & $\mathbf{8 6 4 . 9 6 9}$ & $\mathbf{2 3 3 . 8 4 3}$ & $\mathbf{6 3}$ \\
\hline Çanakkale & & & \\
\hline Ayvacık & 26.191 & 8.063 & 7 \\
\hline Bayramiç & 93.030 & 26.700 & 2 \\
\hline Biga & 155.196 & 51.557 & 2 \\
\hline Çan & 68.445 & 20.439 & 2 \\
\hline Eceabat & 48.905 & 16.539 & 3 \\
\hline Ezine & 10.531 & 12.844 & 6 \\
\hline Merkez & 71.861 & 23.011 & 5 \\
\hline Lapseki & 51.335 & 15.296 & 3 \\
\hline TOPLAM & $\mathbf{5 2 5 . 4 9 4}$ & $\mathbf{1 7 4 . 4 4 9}$ & 30 \\
\hline
\end{tabular}

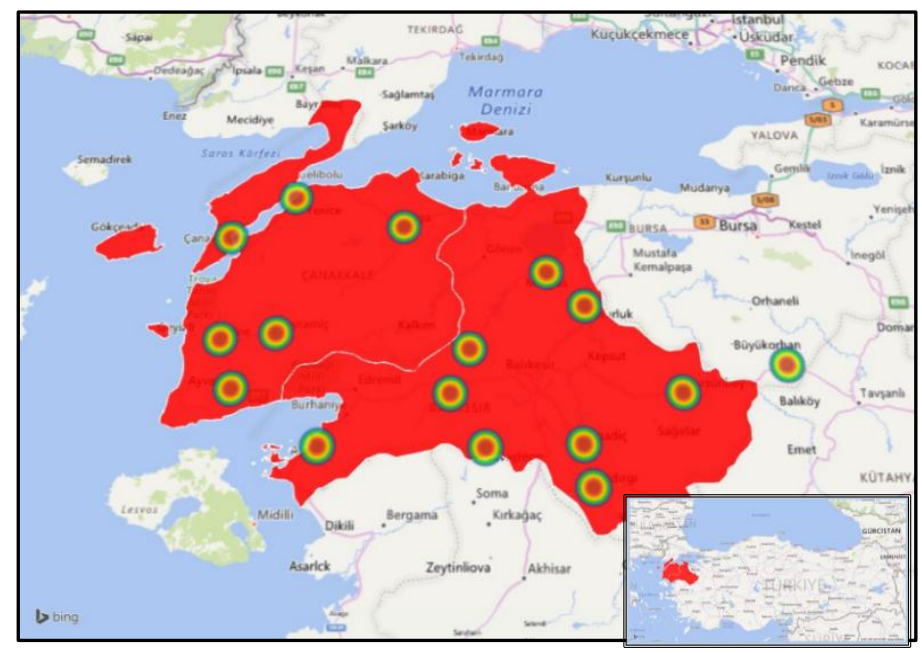

Şekil 1. Buğday örneklerinin alındığı bölge

Örnekler alınırken buğdayın alındığı ilçe/köy, zaman ve çiftçi adı etiketlere yazılmıştır. Buğday çeşitlerinin tamamı kışlık (Ceyhan 99, Sagittario, Kate A-1, Gönen ve Ziyabey-98) olup sulak veya kıraç alanlarda yetişiyor olmaları rastgele seçilmiştir. Laboratuvara getirilen buğday örnekleri tek tek incelenmiş, içerdikleri yabancı ot tohumları, taş, sürmeli daneler, sap, saman ve sağlam daneler ayrılmış ve tohumların teşhisi ve diğer işlemlerin yapılabilmesi için etiketli olarak muhafaza edilmiştir (Şekil 2). Yabancı ot tohumları etiketlenerek teşhis için özel şişelere alınarak koruma altına alınmıştır. Daha sonra örnekler içerisinde bulunan yabancı ot tohumları laboratuvarda morfolojik özelliklerine göre ayrılmıştır. Tohumların teşhisleri için Hafliger ve Scholz, 19801981; Hafliger ve ark., 1982; Basel ve ark., 1988; Hanf, 1983; Özer ve ark., 1999; Davis, 1965-1988)'den yararlanılmıştır. Çalışmada teşhisi yapılamayan yabancı ot tohumları diğerleri olarak belirtilmişstir.
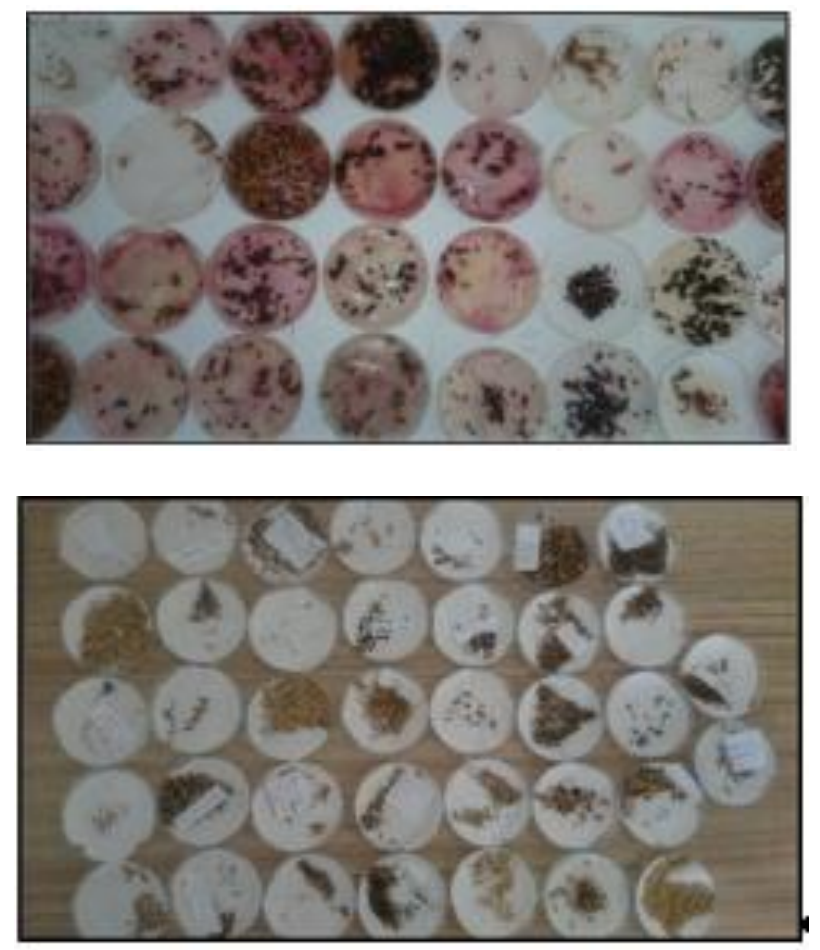

Şekil 2. Toplanan yabancı ot tohumları

Çalışmada yabancı ot tohumlarının buğday ürününe karışım oranları hem sayısal, hem de ağırlık olarak hesaplanmıştır (Güncan, 1980; Sirma ve ark., 1997 ve Tepe, 1998 ). Yabanc1 otlarin hem genel, hem de ilçelere ait ortalama karışım oranları ve dağılımları belirlenmiştir. İstatistiki analizlerde SPSS 20 for Windows Standart Versiyon paket programindan faydalanılmıştır. Kontrol ve uygulama gruplarındaki farklllıklarin belirlenmesinde SPSS 22 paket programında tek yönlü varyans analizi (Genel Linear Model, Univariate) kullanılmıştır. Bu amaçla $\mathrm{P} \leq 0,05$ önemlilik düzeyinde Duncan Çoklu Karşılaştırma Testleri yapılmıştır (Duncan 1955).

\section{BULGULAR}

Balıkesir ve Çanakkale illerinde buğday ürününe karışan yabancı ot tohumları değişik ekolojik koşullar, çeşit faklılığı ve yetiştirme teknikleri (herbisit kullanımı, sulama vs) gibi nedenlerden dolayı ile türler ve yoğunlukları bakımından farklılık göstermiştir. 
Balıkesir İlinde Buğday Ürününe Karışan Yabancı Ot Tohumları

Balıkesir ilinde buğday ürünü içerisine 15 familyaya ait 45 yabancı ot türüne ait tohumunun karıştığı belirlenmiştir (Çizelge 2 ve Çizelge 3).

Çizelge 2. Balıkesir il genelinde buğday ürününe karışan yabancı ot tohumlarının ait olduğu familyalar

\begin{tabular}{|c|c|}
\hline Familyalar & $\begin{array}{c}\text { İcerdiği Tür Sayısı } \\
\text { (adet) }\end{array}$ \\
\hline Apiaceae & 3 \\
\hline Asteraceae (Compositae) & 6 \\
\hline Boraginaceae & 1 \\
\hline Brassicaceae (Cruciferae) & 8 \\
\hline Caryophyllaceae & 4 \\
\hline Convolvulaceae & 1 \\
\hline Fabaceae & 6 \\
\hline Malvaceae & 1 \\
\hline Papaveraceae & 2 \\
\hline Plantaginaceae & 1 \\
\hline Poaceae (Gramineae) & 6 \\
\hline Polygonaceae & 2 \\
\hline Resedaceae & 1 \\
\hline Rosaceae & 1 \\
\hline Rubiaceae & 2 \\
\hline Toplam & $\mathbf{4 5}$ \\
\hline
\end{tabular}

En fazla yabancı ot türü içeren familya buğday ekim alanlarında önemli oranda görülen Brassicaceae familyasıdır (Çizelge 2). İçerdiği yabancı ot tür sayısı itibariyle bu familyayı sırasıyla Asteraceae, Fabacea ve Poaceae (Gramineae) familyaları izlemektedir. Yapılan hesaplamalara göre Balıkesir'de $1 \mathrm{~kg}$ buğday ürünü içerisinde bulunan yabancı ot tohum miktarı; Merkez ilçede 294, Balya'da 164, Bigadiç'te 190, Dursunbey'de 145, Gömeç'de 213, İvrindi'de 350, Kepsut'da 151, Manyas'da 100, Savaştepe'de 314, Sindırgı'da 144 ve Susurluk'da 210 adet bulunmuştur (Çizelge 4). Buna göre en fazla yabancı ot tohum sayısı İvrindi'de, en az yabancı ot tohum sayıs ise Manyas ilçesinde tespit edilmiştir. $1 \mathrm{~kg}$ buğday ürünü içerisinde ağırlıklı il ortalaması olarak 207 adet yabancı ot tohumu saptanmıştır.

Alınan örneklerdeki buğday ürününe karışan yabancı ot tohumlarının ağırlı̆̆ ise; Merkez ilçede $4.94 \mathrm{~g}$, Balya'da 3 g, Bigadiç'de 1.84 g, Dursunbey'de 2.58 g, Gömeç'de $1.78 \mathrm{~g}$, İvrindi'de $3.60 \mathrm{~g}$, Kepsut'da $2.22 \mathrm{~g}$, Manyas'da 3.35 g, Savaştepe'de 5.94 g, Sindırgı'da 2.18 g ve Susurluk'da 2.26 g olarak saptanmıştır (Çizelge 4). Buna göre en fazla yabancı ot tohum ağırlığı Savaştepe'de, en az yabancı ot tohum ağırlığı ise daha küçük tohumlara sahip olan Gömeç ilçesinde belirlenmiştir. Ağırlıklı il ortalaması olarak $1 \mathrm{~kg}$ buğdaya $3.06 \mathrm{~g}$ yabancı ot tohumunun karıştığı belirlenmiştir.
İlçelerin ekolojik faktörlerinin ve ürün yetiştirme periyodunda izledikleri yöntemlerin (sulama, gübreleme, ilaçlama vb.) farklı olmasına bağlı olarak buğday ürününe karışan yabancı ot tohum türleri de özellikle münavebede yapılan yemlik yeşil ot amacıyla ekim yapılan tarlalarda farklılı göstermiştir (Anonim, 2018). Balıkesir Merkez ve İlçe köylerinde 1 $\mathrm{kg}$ buğday ürünü içerisine karışan yabancı ot tür sayıları Balıkesir il genelinde 45, Merkez ilçede 24, Balya'da 17, Bigadiç'de 17, Dursunbey'de 17, Gömeç'de 10, İvrindi'de 17, Kepsut'da 15, Manyas'da 17, Savaştepe'de 24, Sindırgi'da 17 ve Susurluk'da 15'dir. Şekil 3’te Balıkesir il geneli ve ilçelerinde tespit edilen tür sayıları belirtilmiştir.

Balıkesir ilinde buğday ürününe karışan yabancı ot tohumlarının türlere göre sayıları istatistiksel olarak incelendiğinde, yabancı ot türlerine ait tohum sayılarının farklıklarının istatiksel olarak önemli olduğu saptanmıştır. Yapılan istastistiki analiz sonucunda sayısal olarak 4 ve ağırlık olarak ise 7 grup ortaya çıkmıştır. Analiz sonucunda yabani hardal (Sinapis arvensis L.)'in sayısal olarak en fazla sayıda karışan yabancı ot tohumu olduğu belirlenmiştir.

Bunu farklı istatistik grupra yer alan yoğurt otu (Galium aparine L.) takip ederken yine farklı grupta yer alan tarla sarmaşığ $\breve{l}_{1}$ Convolvulus arvensis L.) ve arpa (Hordeum vulgare L.) izlemiştir. Diğer yabancı ot tohumları sayısal olarak aynı grupta yer alarak bu yabancı ot tohumlarını takip etmiştir. En az tohum sayısina sahip yabancs ot ise, melez hardal (Hirschfeldia incana (L.) Lagr. Foss.) tohumu olarak belirlenmiştir. Balıkesir ilinde buğday ürününe karışan yabancı ot tohumlarının yabancı ot türlerine ait tohum ağırlıklarının istatistiksel olarak karşılaştırılması sonucunda farklılıkların önemli olduğu saptanmiştır.

Yapılan istatistiksel analiz sonucunda tahıllar içerinde buğday ekim alanlarından sonra en fazla üretimi yapılan ve bir sonraki yıl buğday ürününe karıştığı tahmin edilen arpa (Hordeum vulgare L.)'nın buğday ürününe yabancı otlar içerisinde ağırlık olarak en yüksek oranda karışan yabancı ot tohumu olduğu belirlenmiştir. Bunu arpa ile aynı grup içerinde yer alan yabani hardal ( $S$. arvensis.) tohumu takip etmiştir. Bunu ayrı bir grup oluşturan yoğurt otu ( $G$. aparine) tohumları izlemiştir. Ağırlık olarak buğday ürününe karışan en az yabancı ot tohumunun küçük turp ( $R$. rugosum) olmasına rağmen istatisitiki olarak aynı grup içerisinde yer alan diğer tohumlar ise Çizelge 3'de verilmiştir.

Balıkesir merkez ilçede $1 \mathrm{~kg}$ buğday ürününe karışma oranında ilk sirayı 154.33 adet ile yabani hardal $(S$. arvensis)'ın aldığ sarmaşı̆̆ı (Convolvulus arvensis L.), yapışkan otu (Galium aparine L.) ve arpa (Hordeum vulgare takip etmektedir. 
1 kg ürüne karışma oranında ağırlık olarak bakıldığında ise ilk sirada $1.112 \mathrm{~g}$ ile korunga (Onobrycis sativa Lam.), belirlenirken bunu yabani hardal (Sinapis arvensis L.), arpa (Hordeum vulgare L.) delice buğdayı (Lolium temulentum L.), yabani hardal (S. arvensis), yabani fiğ (Vicia spp.) ve diğerleri takip etmektedir. Balya ilçesinde $1 \mathrm{~kg}$ buğday ürünü içerisine karışma oranında sayısal olarak ilk sırayı 56.85 adet ile yabani hardal ( $S$. arvensis)'in aldığ belirlenmiştir.

Çizelge 3. Balıkesir il genelinde $1 \mathrm{~kg}$ buğday ürününe karışan yabancı ot tohumlarının sayısal ve ağırlık değerleri

\begin{tabular}{|c|c|c|}
\hline Yabanci otlar & Miktar (adet) & Ağırlık (g) \\
\hline Anchusa officinalis L. & $1.136 \mathrm{C}$ & $0.005591 \quad \mathrm{E}$ \\
\hline Bifora radians Bieb. & $1.055 \mathrm{C}$ & $0.031818 \mathrm{CDE}$ \\
\hline Boreava orientalis Jaub. and Spach. & $1.052 \mathrm{C}$ & $0.076747 \mathrm{CDE}$ \\
\hline Cardaria draba L. & $0.583 \mathrm{C}$ & $0.013873 \mathrm{DE}$ \\
\hline Centaurea depressa Bieb. & $0.359 \mathrm{C}$ & $0.002607 \mathrm{E}$ \\
\hline Chrysanthemum segetum L. & $1.276 \mathrm{C}$ & $0.004727 \mathrm{E}$ \\
\hline Cirsium arvense L. & $1.015 \mathrm{C}$ & $0.008862 \mathrm{E}$ \\
\hline Conium maculatum L. & $0.837 \mathrm{C}$ & $0.010733 \mathrm{E}$ \\
\hline Coriandrum sativum L. & $1.395 \mathrm{C}$ & $0.017184 \mathrm{DE}$ \\
\hline Convolvulus arvensis L. & $18.536 \mathrm{BC}$ & $0.189805 \mathrm{CDE}$ \\
\hline Fumaria officinalis L. & $0.985 \mathrm{C}$ & $0.003741 \mathrm{E}$ \\
\hline Galium aparine $\mathrm{L}$. & $38.200 \mathrm{~B}$ & $0.305819 \mathrm{BC}$ \\
\hline Hirschfeldia incana (L.) Lagr.-Foss. & $0.116 \mathrm{C}$ & $0.007505 \mathrm{E}$ \\
\hline Hordeum murinum L. & $0.156 \mathrm{C}$ & $0.010256 \mathrm{E}$ \\
\hline Hordeum vulgare L. & $16.347 \mathrm{BC}$ & $0.703436 \mathrm{~A}$ \\
\hline Lolium temulentum L. & $2.146 \mathrm{C}$ & $0.033979 \mathrm{CDE}$ \\
\hline Malva neglecta L. & $1.028 \mathrm{C}$ & $0.003764 \mathrm{E}$ \\
\hline Matricaria chamomilla L. & $1.867 \mathrm{C}$ & $0.138874 \mathrm{CDE}$ \\
\hline Medicago polymorpha L. & $0.371 \mathrm{C}$ & $0.000241 \mathrm{E}$ \\
\hline Melilotus officinalis (L.) Pall. & $0.883 \mathrm{C}$ & $0.006850 \mathrm{DE}$ \\
\hline Myagrum perfoliatum L. & $2.015 \mathrm{C}$ & $0.048283 \mathrm{CDE}$ \\
\hline Neslia paniculata (L.) Desv. & $0.559 \mathrm{C}$ & $0.002715 \mathrm{E}$ \\
\hline Onobrycis sativa Lam. & $1.457 \mathrm{C}$ & $0.170629 \mathrm{CDE}$ \\
\hline Panicum repens L. & $0.338 \mathrm{C}$ & $0.015394 \mathrm{DE}$ \\
\hline Papaver rhoeas L. & $4.536 \mathrm{C}$ & $0.021424 \mathrm{DE}$ \\
\hline Phalaris minor Retz. & $1.083 \mathrm{C}$ & $0.007619 \mathrm{E}$ \\
\hline Poa pratensis L. & $2.484 \mathrm{C}$ & $0.000944 \mathrm{E}$ \\
\hline Polygonum convolvulus L. & $1.767 \mathrm{C}$ & $0.008832 \mathrm{E}$ \\
\hline Raphanus raphanistrum $\mathrm{L}$ & $2.240 \mathrm{C}$ & $0.021900 \mathrm{DE}$ \\
\hline Rapistrum rugosum (L.) All. & $0.136 \mathrm{C}$ & $0.000136 \mathrm{E}$ \\
\hline Reseda lutea L. & $0.660 \mathrm{C}$ & $0.003369 \mathrm{E}$ \\
\hline Rubia tinctorum L. & $3.202 \mathrm{C}$ & $0.010978 \mathrm{E}$ \\
\hline Rumex crispus L. & $1.492 \mathrm{C}$ & $0.010147 \mathrm{E}$ \\
\hline Sanguisorba officinalis L. & $0.524 \mathrm{C}$ & $0.002859 \mathrm{E}$ \\
\hline Silene vulgaris L. & $0.877 \mathrm{C}$ & $0.022847 \mathrm{DE}$ \\
\hline Silybum marianum (L.) Gaertner & $0.868 \mathrm{C}$ & $0.006728 \mathrm{E}$ \\
\hline Sinapis arvensis L. & $78.866 \mathrm{~A}$ & $0.533128 \mathrm{~A}$ \\
\hline Sonchus asper (L.) Hill. & $0.507 \mathrm{C}$ & $0.000147 \mathrm{E}$ \\
\hline Spergula arvensis L. & $0.280 \mathrm{C}$ & $0.002214 \mathrm{E}$ \\
\hline Stellaria media (L.) Vill. & $8.260 \mathrm{C}$ & $0.018709 \mathrm{E}$ \\
\hline Vaccaria pyrimidata (L.) Medik. & $1.044 \mathrm{C}$ & $0.013514 \mathrm{DE}$ \\
\hline Veronica hederifolia L. & $1.590 \mathrm{C}$ & $0.003269 \mathrm{E}$ \\
\hline Vicia spp. & $2.915 \mathrm{C}$ & $0.099034 \mathrm{CDE}$ \\
\hline Vicia narbonensis L. & $0.493 \mathrm{C}$ & $0.107912 \mathrm{CDE}$ \\
\hline Vicia villosa Roth. & $0.773 \mathrm{C}$ & $0.018545 \mathrm{DE}$ \\
\hline Diğerleri & $8.808 \mathrm{C}$ & $0.289573 \mathrm{BCD}$ \\
\hline
\end{tabular}




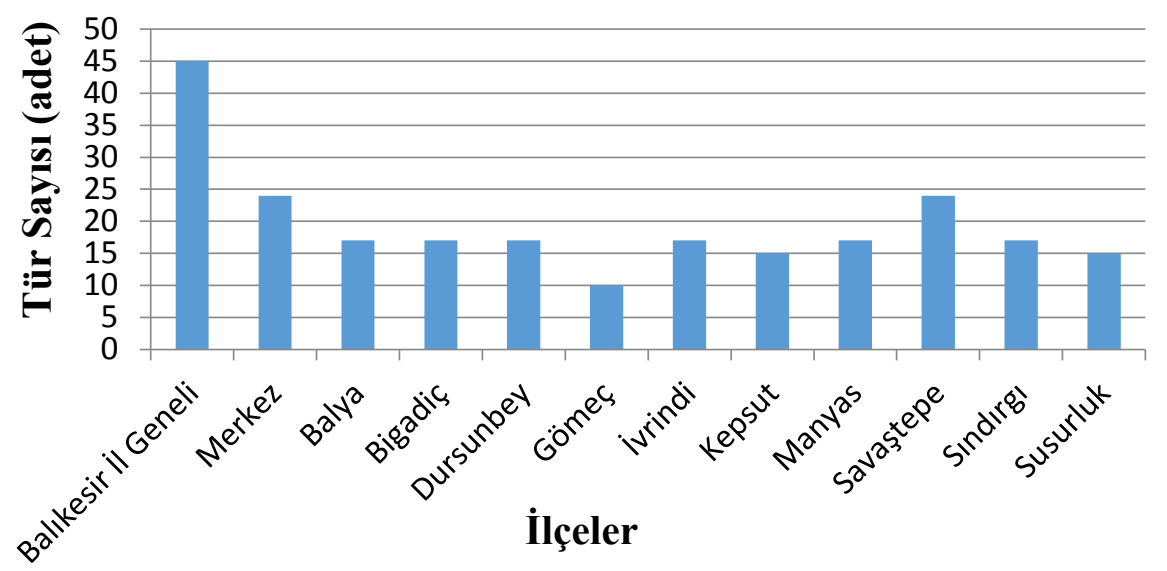

Şekil 3. Balıkesir ilinde buğday ürününe karışan yabancı ot türleri ve miktarı

Çizelge 4. Balıkesir'in ilçelerinde $1 \mathrm{~kg}$ buğday ürününe karışan yabancı ot tohumlarının miktarı ve ağırlıkları

\begin{tabular}{|c|c|c|}
\hline İçeler & $\begin{array}{c}\text { Sayısal Olarak } \\
\text { (adet) }\end{array}$ & $\begin{array}{c}\text { Ağırlık Olarak } \\
(\mathrm{g})\end{array}$ \\
\hline Merkez & 294 & 4.94 \\
\hline Balya & 164 & 3.00 \\
\hline Bigadiç & 190 & 1.84 \\
\hline Dursunbey & 145 & 2.58 \\
\hline Gömeç & 213 & 1.78 \\
\hline İvrindi & 350 & 3.60 \\
\hline Kepsut & 151 & 2.22 \\
\hline Manyas & 100 & 3.35 \\
\hline Savaştepe & 314 & 5.94 \\
\hline Sindırgı & 144 & 2.18 \\
\hline Susurluk & 210 & 2.26 \\
\hline Balıkesir İl Geneli & 207 & 3.06 \\
\hline
\end{tabular}

Bunu sırasıyla arpa ( $H$. vulgare), kişniş otu (Coriandrum sativum L.) ve tarla sarmaşığı ( $C$. arvensis) takip etmektedir. $1 \mathrm{~kg}$ ürüne karışma oranında ağırlık olarak bakıldığında ise ilk sırada $0.8985 \mathrm{~g}$ ile arpa ( $H$. vulgare) belirlenirken bunu yabani hardal ( $S$. arvensis) takip etmiştir.

Bigadiç ilçesinde $1 \mathrm{~kg}$ buğday ürününe karışma oranında sayısal olarak ilk sırayı 64.25 adet ile yabani hardal ( $S$. arvensis)'ın aldığı belirlenmiştir. Bunu sırasıyla yapışkan otu ( $G$. aparine), kuş dili ( $S$. media) ve tarla sarmaşığı ( $C$. arvensis) takip ettiği belirlenmiştir. $1 \mathrm{~kg}$ ürüne karışma oranında ağırlık olarak bakıldığında ise ilk sırada $0.4157 \mathrm{~g}$ ile yabani hardal ( $S$. arvensis) belirlenirken bunu arpa $(H$. vulgare), kişniş otu (C. sativum) ve tarla sarmaşığ ${ }_{1}(C$. arvensis) takip etmiştir.

Dursunbey ilçesinde ise ilk sirayı 31.232 adet ile yabani hardal ( $S$. arvensis)'in aldığı belirlenmiştir. Bunu sirasiyla arpa ( $H$. vulgare), tarla sarmaşığı $(C$. arvensis), yapışkan otu ( $G$. aparine) ve fiğ (Vicia spp.) ve diğerleri izlemiştir. $1 \mathrm{~kg}$ ürüne karışma oranında ağırlık olarak bakıldığında ise ilk sırada $1.0453 \mathrm{~g}$ ile arpa (H. vulgare) belirlenirken bunu fiğ (Vicia spp.), yabani hardal ( $S$. arvensis), tarla sarmaşı̆̆ $(C$. arvensis), yapışkan otu ( $G$. aparine) ve diğer yabancı ot tohumları takip etmektedir.

Gömeç ilçesinde ilk sırayı 151.85 adet ile yapışkan otu ( $G$. aparine)'nun aldığ belirlenirken, bunu sirasıyla kök boya (Rubia tinctorum L.) ve tarla sarmaşığ $(C$. arvensis) izlemiştir. $1 \mathrm{~kg}$ buğday ürününe karışma oranında ağırlık olarak bakıldığında ise ilk sırada $1.2305 \mathrm{~g}$ ile yapışkan otu ( $G$. aparine) belirlenirken, bunu arpa ( $H$. vulgare), yabani hardal ( $S$. arvensis), delice buğdayı ( $L$. temulentum), tarla sarmaşı̆̆ı $(C$. arvensis), ve diğer yabancı ot tohumları takip etmiştir. Balıkesir ili İvrindi ilçesinde en fazla yabani hardalın (S. arvensis) ilk sirayı (252.45 adet) aldığı belirlenmiştir. Bunu sırasıyla arpa $(H$. vulgare $)$ ve yapışkan otu ( $G$. aparine), izlemiştir. Buğday ürüne karışma oranında ağırlık olarak bakıldığında ise 1 kg'lık ürüne $1.6833 \mathrm{~g}$ ile yabani hardal (S. arvensis)'ın en yüksek karışma oranına sahip olduğu belirlenmiştir. Bunu sırasiyla arpa ( $H$. vulgare), korunga (O. sativa), yapışkan otu ( $G$. aparine), kokar ot (Bifora radians Bieb.) ve diğer yabancı ot tohumları takip etmiştir.

Kepsut ilçesinde en yüksek karışma oranı tarla sarmaşığı (C. arvensis)'nda (64.71 adet) belirlenmiştir. Bunu sırasıyla yapışkan otu ( $G$. aparine) ve kuş dili (S. media) izlemiştir. Ağırlık olarak karışma oranına bakıldığında ise 1 kg'lık ürüne $0.8346 \mathrm{~g}$ ile duvar arpası (H. murinum)'nın en yüksek karışma oranına sahip olduğu belirlenmiştir.

Savaştepe ilçesinde ise karışma oranında ilk sırayı 154.33 adet ile yabani hardal ( $S$. arvensis)in aldığı belirlenmiştir. Bunu tarla sarmaşığı (C. arvensis) ve yapışkan otu ( $G$. aparine) izlemiştir. $1 \mathrm{~kg}$ ürüne karışma oranında ağırlık olarak bakıldığında ise ilk surada 1.412 g ile yabani hardal ( $S$. arvensis) belirlenirken, bunu korunga ( $O$. sativa), arpa $(H$. 
vulgare) ve duvar arpası (H. murinum) takip etmiştir. Sındırgı ilçesinde sayısal olarak ilk sırayı 56.85 adet ile yabani hardal ( $S$. arvensis)'in aldığ belirlenmiştir. Bunu sirasiyla arpa ( $H$. vulgare), kişniş otu ( $C$. sativum), tarla sarmaşığı ( $C$. arvensis), tüylü fiğ ( $V$. villosa) ve diğerleri izlemiştir.

Sındırgı'da 1 kg ürüne karışma oranında ağırlık olarak bakıldığında ise ilk sirayı $0.9187 \mathrm{~g}$ ile arpa $(H$. vulgare)'nın aldığı belirlenirken, bunu yabani hardal (S. arvensis), kişniş otu (C. sativum), tarla sarmaşı̆̆g (C. arvensis), yabani turp (Raphanus raphanistrum L.) ve diğer yabancı ot tohumları takip etmiştir.

Susurluk ilçesinde ise ilk sırayı 64.25 adet ile yabani hardal ( $S$. arvensis)'in aldığ görülmektedir. Bunu sırasıyla yapışkan otu ( $G$. aparine), arpa ( $H$. vulgare), kişniş otu (C. sativum), tarla sarmaşı̆̆ ( $C$. arvensis), tüylü fiğ ( $V$. villosa) ve diğerleri izlemiştir. İlçede $1 \mathrm{~kg}$ ürüne karışma oranında ağırlık olarak bakıldığında ise ilk sırayı $0.9187 \mathrm{~g}$ ile arpa (H. vulgare)'nın aldığ belirlenirken, bunu yabani hardal ( $S$. arvensis), kişniş otu (C. sativum), tarla sarmaşı̆̆ turp (Raphanus raphanistrum L.) ve diğer yabanc1 ot tohumları takip etmiştir.

\section{Çanakkale İlinde Buğday Ürününe Karışan Yabancı Ot Tohumları}

Çanakkale ilinde de Balıkesir ilinde olduğu gibi buğday ürünü içerisine 15 familyaya ait 45 yabancı ot tohumunun karıştığı tespit edilmiştir (Çizelge 5 ve Çizelge 6). İki ilin aynı bölge ve ekolojik koşullara sahip olmasından dolayı aynı sayıda familya ve yabanc1 ot tohumuna sahip olduğu söylenebilir. En fazla yabancı ot türünü içeren familyalar Asteraceae ve Brassicaceae familyalarıdır (Çizelge 5).

İçerdiği yabancı ot tür sayısı itibariyle bu familyayı sirasiyla Poaceae (Gramineae) ve Fabaceae familyaları izlemektedir. Çanakkale ilinde $1 \mathrm{~kg}$ buğday içerisine yabanc1 ot türlerinin tohumlarının karışma miktarlarının ilçeler düzeyinde yapılan istatiksel analizler sonucunda farkların \% 5 düzeyinde önemli olmadığ içerisinde sayısal olarak $1 \mathrm{~kg} \mathrm{~kg}^{\prime} \mathrm{lk}$ buğday ürünü içerisine en fazla yabanc1 ot tohumu 244 adet ile Lapseki ilçesinde rastlanırken, bunu Çan (233 adet) Bayramiç (226 adet), Ayvacık (201 adet), Merkez (146 adet), Ezine (146 adet), Eceabat (144 adet) ve Biga (105 adet) ilçeleri izlemiştir (Çizelge 7).

$1 \mathrm{~kg}$ buğday ürünü içerisinde ağırlıklı il ortalaması olarak 181 adet yabancı ot tohum saptanmıştır. Ağırlık olarak ise en fazla karışma $5.14 \mathrm{~g}$ ile Ayvacık ilçesinde rastlanırken, bunu Merkez (4.26 g), Lapseki (3.78 g), Bayramiç (3.41 g), Ezine (2.31 g), Çan (2.30 g) Eceabat $(1.58 \mathrm{~g})$ ve Biga $(1.09 \mathrm{~g})$ ilçeleri takip etmektedir (Çizelge 7). Ağırlıklı il ortalaması olarak $1 \mathrm{~kg}$ buğdaya 2.98 g yabancı ot tohumunun karıştığı belirlenmiştir.
Çizelge 5. Çanakkale il genelinde buğday ürününe karışan yabancı ot tohumlarının ait olduğu familyalar

\begin{tabular}{|c|c|}
\hline Familyalar & İçerdiği Tür Sayısı (adet) \\
\hline Apiaceae & 3 \\
\hline Asteraceae (Compositae) & 8 \\
\hline Boraginaceae & 1 \\
\hline Brassicaceae (Cruciferae) & 8 \\
\hline Caryophyllaceae & 3 \\
\hline Convolvulaceae & 1 \\
\hline Fabaceae & 5 \\
\hline Malvaceae & 1 \\
\hline Papaveraceae & 2 \\
\hline Plantaginaceae & 1 \\
\hline Poaceae (Gramineae) & 6 \\
\hline Polygonaceae & 2 \\
\hline Resedaceae & 1 \\
\hline Rosaceae & 1 \\
\hline Rubiaceae & 2 \\
\hline Toplam & $\mathbf{4 5}$ \\
\hline
\end{tabular}

Balıkesir'de olduğu gibi Çanakkale ve ilçelerinde de ekolojik faktörlerin ve ürün yetiştirme periyodunda izledikleri yöntemlerin (sulama, gübreleme, ilaçlama vb.) farklı olmasına bağlı olarak buğday ürününe karışan yabancı ot tohum türleri de farklılık göstermiştir.

Çanakkale Merkez ve İlçe köylerinde $1 \mathrm{~kg}$ buğday ürünü içerisine karışan yabancı ot tür sayıları Çanakkale il genelinde 45, Merkez ilçede 27, Ayvacık'da 22, Bayramiç'de 18, Biga'da 9, Çan'da 14, Eceabat'da 22, Ezine'de 14 ve Lapseki'de 13'dür.

Şekil 4'te Çanakkale il geneli ve ilçelerinde tespit edilen tür sayıları belirtilmiştir. Çanakkale ilinde buğday ürününe karışan yabancı ot tohum sayıları istatistiksel olarak karşılaştırıldığında yabancı ot türlerine ait tohum sayılarının farklıklarının önemli olduğu saptanmıştır. Yapılan istatistiki analiz sonucunda sayısal olarak 8 ve ağırlık olarak ise 4 grup ortaya çıkmıştır. Analiz sonucunda yoğurt otu ( $G$. aparine )'nun en fazla sayıda karışan yabancı ot tohumu olduğu ve bunu yine istatistiki olarak aynı grup içerisinde bulunan yabani hardal ( $S$. arvensis) tohumunun takip ettiği belirlenmiştir (Çizelge 6).

$\mathrm{Bu}$ tohumları farklı grupta yer alan tarla sarmaşığı (C. arvensis) takip etmiştir. . En az tohum sayısına sahip yabanc1 ot ise, meryem dikeni (Silybum marianum (L.) Gaertner) olduğu saptanmıştır. Yabancı ot türlerine ait tohum ağırlıklarının istatistiksel olarak karşılaştırılması sonucunda farklılıkların önemli olduğu saptanmıştır.

İstatistiksel analiz sonucunda arpa ( $H$. vulgare)'nın buğday ürününe yabancı otlar içerisinde ağırlık olarak en yüksek oranda karıştığı ve ayrı bir grup oluşturduğu belirlenmiştir. Bunu ayrı grup içerisinde bulunan yoğurt otu ( $G$. aparine) takip etmiştir. 
Çizelge 6. Çanakkale il genelinde $1 \mathrm{~kg}$ buğday ürününe karışan yabancı ot tohumlarının sayısal ve ağırlık değerleri

\begin{tabular}{|c|c|c|}
\hline Yabancı otlar & Miktar (adet) & Ăğılık (g) \\
\hline Anchusa officinalis L. & $3.025 \mathrm{DE}$ & $0.0137750 \mathrm{C}$ \\
\hline Bifora radians Bieb. & $1.906 \mathrm{DE}$ & $0.1254500 \mathrm{BC}$ \\
\hline Boreava orientalis Jaub at. & $0.718 \mathrm{E}$ & $0.0610000 \mathrm{C}$ \\
\hline Cardaria draba L. & $1.411 \mathrm{DE}$ & $0.0452875 \mathrm{C}$ \\
\hline Centaurea depressa BIEB. & $0.750 \mathrm{E}$ & $0.00795 \mathrm{C}$ \\
\hline Chrysanthemum segetum L. & $1.200 \mathrm{DE}$ & $0.0086375 \mathrm{C}$ \\
\hline Cirsium arvense L. & $0.391 \mathrm{E}$ & $0.0033250 \mathrm{C}$ \\
\hline Conium maculatum L. & $0.357 \mathrm{E}$ & $0.0045750 \mathrm{C}$ \\
\hline Convolvulus arvensis $\mathrm{L}$. & $18.96 \mathrm{~B}$ & $0.1888000 \mathrm{BC}$ \\
\hline Coriandrum sativum L. & $5.136 \mathrm{DE}$ & $0.0030875 \mathrm{C}$ \\
\hline Crepis foetida $\mathrm{L}$. & $0.314 \mathrm{E}$ & $0.0994875 \mathrm{BC}$ \\
\hline Fumaria officinalis L. & $2.924 \mathrm{DE}$ & $0.0111125 \mathrm{C}$ \\
\hline Galium aparine L. & $35.18 \mathrm{~A}$ & $0.3025625 \mathrm{~B}$ \\
\hline Hirschfeldia incana (L.) Lagr.-Foss & $0.563 \mathrm{E}$ & $0.0362875 \mathrm{C}$ \\
\hline Hordeum murinum L. & $0.150 \mathrm{E}$ & $0.0111250 \mathrm{C}$ \\
\hline Hordeum vulgare $\mathrm{L}$. & $14.07 \mathrm{BC}$ & $0.5585000 \mathrm{~A}$ \\
\hline Lolium temulentum $\mathrm{L}$. & $2.568 \mathrm{DE}$ & $0.0348875 \mathrm{C}$ \\
\hline Malva neglecta L. & $1.624 \mathrm{DE}$ & $0.0057625 \mathrm{C}$ \\
\hline Matricaria chamomilla L. & $4.660 \mathrm{DE}$ & $0.2032875 \mathrm{BC}$ \\
\hline Medicago polymorpha L. & $1.833 \mathrm{DE}$ & $0.0446000 \mathrm{C}$ \\
\hline Melilotus officinalis (L.) DESR. & $1.376 \mathrm{DE}$ & $0.0121000 \mathrm{C}$ \\
\hline Myagrum perfoliatum $\mathrm{L}$. & $2.089 \mathrm{DE}$ & $0.0530625 \mathrm{C}$ \\
\hline Neslia paniculata (L.) Desv. & $1.860 \mathrm{DE}$ & $0.0060250 \mathrm{C}$ \\
\hline Onobrycis sativa L. & $0.435 \mathrm{E}$ & $0.0914750 \mathrm{BC}$ \\
\hline Panicum repens L. & $0.214 \mathrm{E}$ & $0.0108625 \mathrm{C}$ \\
\hline Papaver rhoeas L. & $6.991 \mathrm{CDE}$ & $0.0153125 \mathrm{C}$ \\
\hline Phalaris minor Retz. & $2.550 \mathrm{DE}$ & $0.0191500 \mathrm{C}$ \\
\hline Poa pratensis L. & $0.475 \mathrm{E}$ & $0.0001875 \mathrm{C}$ \\
\hline Polygonum convolvulus $\mathrm{L}$. & $0.500 \mathrm{E}$ & $0.0025000 \mathrm{C}$ \\
\hline Raphanus raphanistrum L. & $4.275 \mathrm{DE}$ & $0.0495000 \mathrm{C}$ \\
\hline Rapistrum rugosum (L.) All. & $0.802 \mathrm{E}$ & $0.0008000 \mathrm{C}$ \\
\hline Reseda lutea L. & $0.100 \mathrm{E}$ & $0.0006000 \mathrm{C}$ \\
\hline Rubia tinctorum L. & $2.650 \mathrm{DE}$ & $0.0151000 \mathrm{C}$ \\
\hline Rumex crispus L. & $1.609 \mathrm{DE}$ & $0.0109375 \mathrm{C}$ \\
\hline Sanguisorba officinalis L. & $1.456 \mathrm{DE}$ & $0.0088750 \mathrm{C}$ \\
\hline Silybum marianum (L.) & $0.107 \mathrm{E}$ & $0.0002125 \mathrm{C}$ \\
\hline Sinapis arvensis L. & $31.65 \mathrm{~A}$ & $0.2050625 \mathrm{BC}$ \\
\hline Sonchus asper (L.) Hill. & $0.300 \mathrm{E}$ & $0.0000875 \mathrm{C}$ \\
\hline Spergula arvensis L. & $0.982 \mathrm{E}$ & $0.0004375 \mathrm{C}$ \\
\hline Stellaria media (L.) Vill. & $11.08 \mathrm{BCD}$ & $0.0037000 \mathrm{C}$ \\
\hline Tragopogon pratensis L. & $0.264 \mathrm{E}$ & $0.0026000 \mathrm{C}$ \\
\hline Vaccaria pyrimidata (L.) Medik. & $0.763 \mathrm{E}$ & $0.0054875 \mathrm{C}$ \\
\hline Veronica hederifolia L. & $2.311 \mathrm{DE}$ & $0.0018500 \mathrm{C}$ \\
\hline Vicia spp. & $6.220 \mathrm{CDE}$ & $0.0995250 \mathrm{C}$ \\
\hline Vicia narbonensis $\mathrm{L}$. & $0.717 \mathrm{E}$ & $0.1740875 \mathrm{BC}$ \\
\hline Diğerleri & $2.053 \mathrm{DE}$ & $0.2213500 \mathrm{BC}$ \\
\hline
\end{tabular}


Çizelge 7. Çanakkale'nin ilçelerinde $1 \mathrm{~kg}$ buğday ürününe karışan yabancı ot tohumlarının miktarı ve ağırlıkları

\begin{tabular}{|l|c|c|}
\hline İlçeler & $\begin{array}{c}\text { Sayısal Olarak } \\
\text { (adet) }\end{array}$ & $\begin{array}{c}\text { Ağırlık Olarak } \\
\text { (g) }\end{array}$ \\
\hline Merkez & 146 & 4.26 \\
\hline Ayvacık & 201 & 5.14 \\
\hline Bayramiç & 226 & 3.41 \\
\hline Biga & 105 & 1.09 \\
\hline Çan & 233 & 2.30 \\
\hline Eceabat & 144 & 1.58 \\
\hline Ezine & 146 & 2.31 \\
\hline Lapseki & 244 & 3.78 \\
\hline Çanakkale İl Geneli & $\mathbf{1 8 1}$ & $\mathbf{2 . 9 8}$ \\
\hline
\end{tabular}

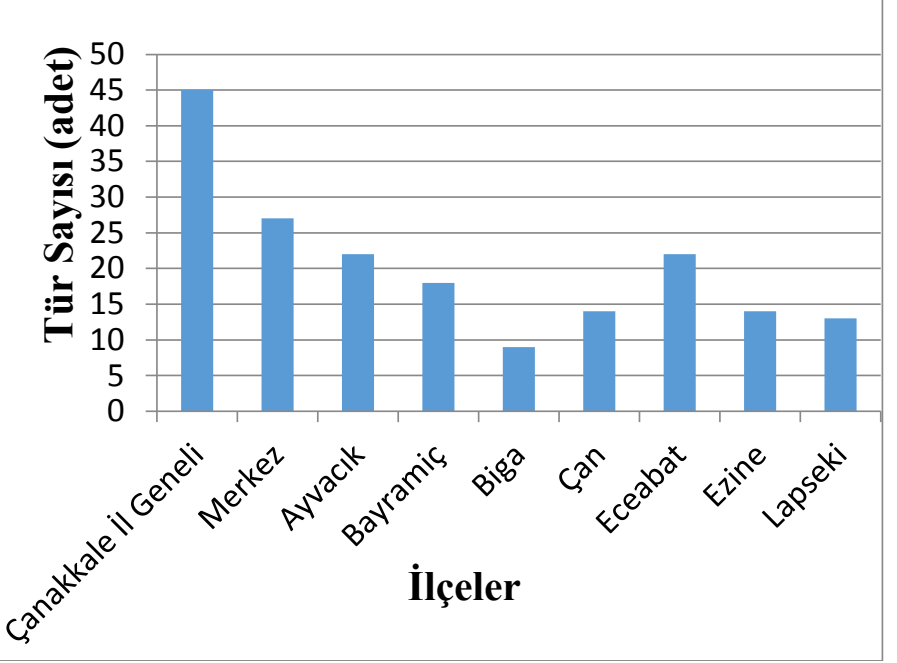

Şekil 4. Çanakkale ilinde buğday ürününe karışan yabancı ot tür sayıları

Bunları ise aynı grupta yer alan diğer yabancı ot tohumları, yabani hardal ( $S$. arvensis.), gerçek papatya (Matricaria chamomilla L.), tarla sarmaşığ (C. arvense) ve koca fiğ ( $V$. narbonensis L.) tohumları izlemiştir. Ağırlık olarak buğday ürününe karışan en az yabancı ot tohumunun küçük turp ( $R$. rugosum) olduğu belirlenmiştir (Çizelge 6).

Çanakkale merkez ilçede buğdaya karışma oranında sayısal olarak ilk sırayı 17.40 adet ile yapışkan otu $(G$. aparine)'n aldığı belirlenmiştir. Bunu sırasıyla sarı papatya (Chrysanthemum segetum L.), tarla sarmaşı̆̆ı (C. arvensis) ve toplu iğne hardalı (Neslia paniculata (L.) takip etmektedir. 1 kg'llk buğday ürününe karışma oranında ağırlık olarak bakıldığında ise ilk sirada $0.1878 \mathrm{~g}$ ile kokar ot (Bifora radians Bieb.) yer almıştır. Ayvacık ilçesinde sayısal olarak ilk sırayı 66.85 adet ile tarla sarmaşığı ( $C$. arvensis)'nın aldığı belirlenmiştir. Bunu sirasıyla yabani hardal ( $S$. arvensis), kişniş (C. sativum), yapişkan ot ( $G$. aparine), kaba yonca (Medicago polymorpha L.), ve diğerleri takip etmektedir.

Ağırlık olarak incelendiğinde ise ilk sırada $0.7959 \mathrm{~g}$ ile pis kokulu hindiba (Crepis foetida L.) belirlenirken, bunu kaba yonca (Medicago polymorpha L.), tarla sarmaşığı $(C$. arvensis), arpa ( $H$. vulgare L.), yabani hardal ( $S$. arvensis) ve diğerleri takip etmektedir.

Bayramiç ilçesinde ise karışma oranında sayısal olarak ilk sırayı 39.00 adet ile yapışkan otu $(G$. aparine)'n aldığı belirlenmiştir. Bunu sırasıyla yabani hardal ( $S$. arvensis), kuşdili ( $S$. media), yavşan otu (Veronica hederifolia L.), papatya (Matricaria chamomilla L.) ve diğerleri takip ettiği belirlenmiştir. İlçede $1 \mathrm{~kg}$ ürüne karışma oranında ağırlık olarak bakıldığında ise ilk sırada $0.3354 \mathrm{~g}$ ile yapısskan ot ( $G$. aparine) belirlenirken, bunu gönül hardalı (Myagrum perfoliatum L takip etmiştir.

Biga ilçesinde sayısal olarak karışma düzeyleri incelendiğinde ilk sırayı 33.00 adet ile yabani hardal (S. arvensis)'in aldığı belirlenmiştir. Bunu sırasıyla tarla sarmaşı̆̆ı ( $C$. arvensis), yapışkan otu ( $G$. aparine) gelincik (Prhoeas), kuş yemi (Phalaris minor Retz.) ve diğerleri izlemiştir. İlçede $1 \mathrm{~kg}$ ürüne karışma oranında ağırlık olarak bakıldığında ise ilk sirada $0.3825 \mathrm{~g}$ ile yabani tere $(C$. draba), belirlenirken bunu yabani hardal ( $S$. arvensis), tarla sarmaşığı $(C$. arvensis), fiğ (Vicia spp.) ve diğer yabancı ot tohumları takip etmektedir.

Çan ilçesinde sayısal olarak ilk sırayı 69.00 adet ile yabani hardal (S. arvensis) aldığ belirlenmiștir. Bunu sirasıyla fiğ (Vicia spp.), yapışkan otu (G. aparine), sığırdili (Anchusa officinalis L.), yabani turp ( $R$. raphanistrum), tarla sarmaşığı (C. arvensis) ve diğerleri izlemiştir. $1 \mathrm{~kg}$ ürüne karışma oranında ağırlık olarak bakıldığında ise $0.5520 \mathrm{~g}$ ile fiğ (Vicia spp.) ilk sırada ortaya çıkmıştır. Bunu sırasıyla yabani hardal ( $S$. arvensis), yabani yonca ( $M$. polymorpha), yabani turp ( $R$. raphanistrum), tarla sarmaşı̆̆ı $(C$. arvensis), yapışkan otu ( $G$. aparine) ve diğer yabancı ot tohumları takip etmiştir.

Eceabat ilçesinde buğdaya sayısal olarak en fazla tarla sarmaşığı (C. arvensis) ilk sırayı (27.00 adet) aldığı belirlenmiştir. Bunu sirasiyla yabani hardal ( $S$. arvensis), gelincik ( $P$. rhoeas), kök boya (Rubia tinctorum L.), arpa (H. vulgare), yabani tere (C. draba) ve diğer yabancı ot tohumları izlemiştir. Buğday ürüne karışma oranında ağırlık olarak bakıldığında ise 1 kg'llk ürüne $0.2580 \mathrm{~g}$ ile yapışkan otu $(G$. aparine) en yüksek karışma oranına sahip olduğu belirlenmiştir. Bunu sırasıyla tarla sarmaşığ vulgare), yabani tere ( $C$. draba), yabani hardal ( $S$. arvensis) ve diğer yabancı ot tohumları takip etmiştir. Ezine ilçesinde en yüksek karışma oranı yapışkan otu (G. aparine)'nda (79.20 adet) belirlenmiştir. Bunu sirasiyla arpa ( $H$. vulgare), kök boya ( $R$. tinctorum), tarla sarmaşığı ( $C$. arvensis), dikenli eşek marulu (Sonchus asper (L.) Hill.) ve diğer yabancı ot tohumları izlemiştir. Ağırlık olarak karışma oranına bakıldığında ise $1 \mathrm{~kg}$ 'lık ürüne $1.1672 \mathrm{~g}$ ile arpa $(H$. vulgare)' nın en yüksek karışma oranına sahip olduğu 
belirlenmiştir. Bunu sırasıyla yapışkan otu ( $G$. aparine), kök boya ( $R$. tinctorum), tarla sarmaşı̆̆ $(C$. arvensis) kokulu sarı yonca (Melilotus officinalis (L.) Desr.) ve diğer yabancı ot tohumları takip etmiştir.

Lapseki ilçesinde ise sayısal olarak en yüksek karışma oranı yabani hardal ( $S$. arvensis) 'da (71.00 adet) belirlenmiştir. Bunu sırasıyla yapışkan otu $(G$. aparine), arpa ( $H$. vulgare), toplu iğne hardalı ( $N$. apiculata), gelincik ( $P$. rhoeas) ve diğer yabancı ot tohumları izlemiştir. Ağırlık olarak karışma oranına bakıldığında ise $1 \mathrm{~kg}$ 'lı ürüne $2.5805 \mathrm{~g}$ ile arpa $(H$. vulgare)' nın en yüksek karışma oranına sahip olduğu belirlenmiştir. Bunu sırasıyla yapışkan otu ( $G$. aparine), yabani hardal ( $S$. arvensis), arap baklası (Vaccaria pyrimidata (L.) Medik.), toplu iğne hardalı ( $N$. apiculata) ve diğer yabancı ot tohumları takip etmiştir.

\section{TARTIŞMA ve SONUÇ}

Çalışmanın yapıldığı illerde daha önce buğday ürününe karışan yabancı ot tohumları ile ilgili herhangi bir çalışma yapılmamıştır. Çalışmadan elde edilen sonuçlar bu bölge için ilk olma özelliği taşımaktadır. Çalışmada elde edilen sonuçlara göre buğday ürününe yabancı ot tohumları ağırlık olarak Balıkesir'de $3.06 \mathrm{~g}$ (\% 0.306) ve Çanakkale'de ise 2.98 g (\% 0.298) oranında karıştığı belirlenmiştir. $1 \mathrm{~kg}$ buğday ürününe sayısal olarak Balıkesir'de 206.78, Çanakkale'de ise 180.59 adet yabancı ot tohumlarının karıştığı belirlenmiştir. Her iki ilin ekolojik ve iklimsel özellikleri bakımından birbirine yakın olması ve buğday yetiştiriciliğinde yabancı ot mücadele şekillerinin de benzer olmasından dolayı (özellikle herbisit kullanımının yaygınlığı) yabancı otların ağırlık ve sayısal olarak her iki ilde de birbirine yakın değerler bulunmuştur. Diğer taraftan her iki ilde de buğday ürünü içerisine 15 familyaya ait 45 farklı yabancı ot tohumunun karışması da yine her iki ilin birbirine yakın özelliklerinden olan ekolojik, iklimsel ve ürün desenlerinden kaynaklandığ düşünülmektedir.

Balıkesir ili Manyas ilçesi buğday ekim alanlarında bazı önemli yabancı ot türlerinin tohumlarının topraktaki yoğunluk ve rastlanma siklığ topraktaki tohum rezervi ve yabanc1 ot florası arasındaki ilişki araştırılmış ve yapılan çalışmalar sonucunda Avena sp., Galium tricornutum Dandy ve Sinapsis arvensis L., Vaccaria pyrimidata (L.) Medik., Lolium sp. ve Neslia paniculata (L.) Desv. yabanc1 ot türleri önemli türler olarak bildirilmiştir (Topuz ve Nemli, 2002). Elde edilen bu sonuçlar hem Balıkesir hem de Çanakkale illerinde buğday ürününe karışan yabancı ot tohumları ile benzerlikler göstermektedir. Bu türler içerinde yer alan $S$. arvensis yabancı otunun tohumları önemli düzeyde buğday ürününe de karıştığı saptanmıştır.

Türkiye'de buğdaya karışan yabancı ot tohumlarının belirlenmesi üzerine yapılan değişik çalışmalar bulunmaktadır. Bu çalışmalardan bazıları bu çalışma sonuçlarına benzerlikler gösterirken bazılarında ise farklılıklar ortaya çıkmaktadır. Tursun (1995), Sivas ilinde buğdaya yabancı ot tohumlarının ağırlık olarak \% 0.3-2 arasinda, Zengin (1996), Erzurum Bölgesi'nde ise buğday ürünü içerisine 95 tür yabancı ot tohumunun karıştığını ve bu yabancı ot tohumlarının sayısal olarak 72.1 adet, ağırlık olarak ise $20.4 \mathrm{~g}$ oranında olduğunu belirlemiştir. Yine Van'da yürütülen çalışmada $1 \mathrm{~kg}$ 'llk ürüne sayısal olarak ortalama 4892 adet, ağırlık olarak ise $131.1 \mathrm{~g}$ oranında yabancı ot tohumlarının karıştığı (Tepe, 1998). Adlyaman (205.83 adet $/ \mathrm{kg})$ ve Kahramanmaraş'ta (164.97 adet/kg) buğday ürününe en fazla Sinapis arvensis L.'in, Gaziantep'te $(260.22$ adet $/ \mathrm{kg})$ ise Hordeum vulgare L.'nin en fazla oranda karıştığı Kantarcı (2004) tarafindan belirlenmiştir. Yine aynı çalışmada, ağırlık olarak en fazla karışım oranı her üç ilde de Hordeum vulgare L.'nin olduğu belirlenmiştir. 1 kg ürününde; Adıyaman ilinde sayısal olarak ortalama 801.89 adet ve ortalama ağırlık olarak 16.72 g, Gaziantep ilinde ortalama 680.54 adet ve ağırlık olarak 15.32 g ve Kahramanmaraş ilinde sayısal olarak ortalama 601 adet ve ağırlık olarak ortalama $10.51 \mathrm{~g}$ olarak belirtilmiştir (Kantarcı, 2004). Mardin ilinde yapılan çalışmada ise yabancı ot tohum sayısı 973.05 adet, ağırlık ve karışım oranı ise 15.16 ve \% 1.52 olarak belirlenmiştir. Tespit edilen yabancı ot tohumları arasında ilk sirayı 194.69 adet ile $A$. sterilis almış bunu $S$. arvensis (191.69)' in izlediğini tespit edilmiştir (Gökalp ve Üremiş 2015). Balıkesir il genelinde sayısal olarak en fazla karışan yabancı otun Sinapis arvensis L. $\quad(77.53$ adet $/ \mathrm{kg})$ olduğu belirlenirken, ağırlık olarak ise Hordeum vulgare L. $(0.7034 \mathrm{gr} / \mathrm{kg})$ olduğu saptanmıştır. Çanakkale il genelinde buğday ürününe karışan yabancı ot tohumları incelendiğinde; sayı olarak $G$. aparine nin (35.18 adet $/ \mathrm{kg})$ en fazla karışan yabancı ot olduğu, ağırlık olarak ise $H$. vulgare $(0.558 \mathrm{gr} / \mathrm{kg})$ en fazla buğday ürününe karışan yabancı ot olduğu belirlenmiştir.

Bu çalışmalardan elde edilen sonuçlar bu çalışmada saptanan değerlerden daha yüksek bulunmuştur. Bunun da muhtemelen buğdayda yabanc1 ot ilaçlarının Balıkesir ve Çanakkale illerinde daha fazla kullanımından kaynaklanmasindan ortaya çıkmaktadır (GTHB, 2015). Özellikle $S$. arvensis'in buğdayın önemli bir yabancı otu olmasından dolayı yapılan bazı çalışmalarda ve bu çalışmada en fazla saptanan türlerden biri olarak saptanmıştır.

Buğday ürünü içerisine karışan yabancı ot tohumlarını belirlemek amaciyla Tokat ilinde yürütülen çalışmada ise ürüne karışan yabancı ot tohumlarının oranı ortalama \% 0.57 olarak tespit edilmiştir. Karışan yabancı ot tohumları incelendiğinde 16 farklı familyadan 49 farklı yabancı 
ot türü belirlenmiştir. Çalışma sonucunda en çok karışımın Poaceae familyası üyelerine ait olduğu saptanmıştır (Şin ve ark., 2016). Yapılan çalışmalarda Poaceae familyasına ait yabancı ot türlerinin tohumlarının buğday ürününe karışan karıştığ tespit edilmiştir. Ancak yapılan çalışmada özellikle Balıkesir'de Brassiceae, Çanakkale'de ise hem Brassiceae ve hem de Asteraceae familyasina ait türlere fazla miktarda rastlanılmıştır. Poaceae familyasina bu familyalar kadar fazla rastlanılmamasının nedeni il genelinde tahıllarda dar yapraklı yabancı otlara karşı herbisit kullanımının yaygın olmasından kaynaklandığını söyleyebiliriz. Buna bağlı olarak da çalışmanın sonucunda geniş yapraklı yabancı otların buğday ürününe fazla miktarda karıştığı belirlenmiştir.

Buğdayda sorun olan yabancı otların mücadelesine yönelik etkin kararlar vermek için survey çalışmaları ve buğday ürünü içerisine karışan yabancı ot tohumlarının belirlenmesine yönelik çalışmaların yapılması gerekmektedir. Bu çalışmada Balıkesir ve Çanakkale illerinde buğday üretim alanlarında yabanc1 otlarla mücadelede genellikle herbisit mücadelesi yapılmakta olduğu ortaya çıkmaktadır. Tüm ilçelerde $S$. arvensis, $G$. aparine, $C$. arvensisin ilk sıralarda oluşu bu yabancı otların istilacı özelliklerinin ve bu yabancı otlara karşı yoğun olarak herbisit kullanılmasına rağmen büyük sorun oluşturmaya devam etmektedir (USDA, 2018). Bu duruma bağlı olarak araştırmadan elde edilen sonuçlar incelendiğinde; buğday'ın ürün rotasyonuna girmeden yetiştiriciliğinin devam etmesi, istilacı türlerin ön planda olması ve herbisit dayanıklılığının ortaya çıkması gibi nedenlerle yabancı ot bulaşma oranlarının ortaya çıktığı düşünülmektedir.

$\mathrm{Bu}$ çalışma sonucunda buğdaydaki kayıpların belirlenmsinde yabancı ot tür ve yoğunluğuna göre mücadeleye odaklanılmasında önemli bir veri sunmaktadır. $\mathrm{Bu}$ da bölgede alınabilecek yabancı ot entegre mücadele yöntemlerinin tür ve yoğunluğuna göre belirlenmesinde yol gösterici olacaktır. Pestisitin kullanımı incelendiğinde; Ege bölgesi Türkiye'de kullanılan pestisitlerin \% 17 oranında önemli paya sahiptir. Kullanılan pestisitlerden herbisitler ise en fazla kullanılan 2. pestisitlerdir. Bunların içerisinde 2,4-D en fazla oranda kullanılan herbisit aktif maddesi olarak ortaya çıkmaktadır (Kaymak ve ark., 2015). Ayrıca bölgede yoğun olarak belirlenen yabancı otlardan S. arvensis (Topuz, 2007) ve bazı geniş yapraklı ve Avena fatua L. ve Avena. sterilis L. (Türkseven, 2011) gibi dar yapraklı yabancı otların yüksek düzeyde dayanıklılıklarının belirlenmiş olması birçok yabancı otla ilgili bu olgunun gelişmiş olabileceğini ortaya koymaktadır.

Çalışma sonunda $1 \mathrm{~kg}$ ürüne ortalama, Balıkesir il genelinde 207 adet, ağırlık olarak ise $3.06 \mathrm{~g}$ yabancı ot tohumunun karıştığı, Çanakkale il genelinde ise 181 adet ve $2.98 \mathrm{~g}$ yabancı ot tohumu karıştığ hesaplanmıştır. Her iki ilde de buğday ürünü içerisine 15 familyaya ait 45 farkl yabancl ot tohumunun karıștığ Balıkesir de hem de Çanakkale illerinde olduğu gibi Türkiye'de yabancı ot tohumları ile bulaşık buğday tohumluluğunun tekrar tarlaya ekilmesiyle yabancı otların yayılmasının ve oluşabilecek ürün kayıplarının önlenmesi ancak temiz ve sertifikalı tohum kullanılması ile sağlanabilecektir.

\section{KAYNAKLAR}

Anonim 2016. Türkiye İstatistik Kurumu, Bitkisel Üretim İstatistikleri. https://biruni.tuik.gov.tr/ medas $/ ? \mathrm{kn}=92 \&$ locale $=$ tr. $\quad$ Erişim tarihi: 20.10.2017.

Anonymous 2017. Food and Agriculture Organization of The United Nations, http://www.fao.org/faosta t/en/\#data/QC Erişim tarihi: 26.12.2017.

Anonim 2018. Balıkesir il Tarım, Orman Müdürlüğü, Faliyet Raporu, 2016 yılı tüik verilerine göre balıkesir ilinde öne çıkan ürünler https://balikesir.tarimorman.gov.tr/Menu/55/Faali yet-Raporu Erişim tarihi: 12.12.2018.

Basel TJ, Wolf M 1988. Dicot Weeds 1, Documenta, Ciba-Geigy Ltd., Basle, Switzerland.

Baş A 2011. Doğu Karadeniz Bölgesinde Buğday Ürününe Karışan Yabancı Ot Tohumlarının Tespiti ve Dağılışları. Selçuk Üniversitesi Fen Bilimleri Enstitüsü, Bitki Koruma Ana Bilim Dalı Yüksek Lisans Tezi, 73s, Konya.

Bates LS, Heyne EG 1980. American Soc. of Agr., Crop Sci., Soc. of America, Madison, Wisconsin, 95-111.

Borlaugh NE 1982. Feeding mankind in the 1980's the role of international agricultural research, Ann. Agr. Sec. Symp., World Bank, 33p., Washington D.C.

Bozkurt M 2018. Muş ilinde buğday ürününe karışan yabancı ot tohumlarının belirlenmesi. İnönü Üniversitesi Fen Bilimleri Enstitüsü Bitki Koruma Ana Bilim Dalı, 48s, Malatya.

Davis PH 1965-1988. Flora of Turkey and East Aegean Island. Vol:1-10, Edinburg, UK.

Duncan DB 1955. Multiple Range and Multiple F-Test. Biometrics, 11: 1-5.

GTHB 2015. Gıda Tarım ve Hayvancılık Bakanlığı, Gıda ve Kontrol Genel Müdürlüğü, Bitki Sağlığı ve Karantina Daire Başkanlığı.

Gökalp Ö, Üremiş İ 2015. Mardin'de buğday ürününe karışan yabancı ot tohumlarının belirlenmesi. MKÜ Ziraat Fakültesi Dergisi, 20 (1) : 23-30.

Güncan A 1980. Anadolu'nun Doğusunda Buğday Ürününe Karışan Yabancı Ot Tohumları, Bunların Yoğunlukları ve Önemlilerinin Oluşturdukları Bitki Toplulukları (Assosiation) Üzerinde Bir Araştırma. Türkiye II. Herboloji Kongresi, s,289.

Hafliger E, Kühn U, Hamet-Ahti L, Cook DKC, Faden R, Speta F 1982. Monocot Weeds 3, Documenta, 
Ciba-Geigy Ltd., Basle, Switzerland, 132p.

Haflige, E, Scholz B, Scholz H 1980. Grass Weeds 1., Documenta, Ciba-Geigy Ltd., Basle, Switzerland, $142 \mathrm{p}$.

Hafliger E, Scholz H 1981. Grass Weeds 2., Documenta, Ciba-Geigy Ltd., Basle, Switzerland, $138 \mathrm{p}$.

Hanf M 1983. The Arable Weeds of Europe with Their Seedling and Seeds. BASF United Kingdom Limited, Lady Lane, Hadleigh, Suffolk, UK, 494p.

İnan İH, Rehber E 1987. Türkiye'de tahıl üretiminin ekonomik yapısı ve sorunları. Türkiye Tahıl Semp., (6-9 Ekim 1987, Bursa) 665-673.

Kantarcı Z 2004. Kahramanmaraş, Adıyaman ve Gaziantep illerinde buğday ürününe karışan yabancı ot tohumlarının belirlenmesi üzerine araştırmalar. Kahramanmaraş Sütçü İmam Üniversitesi Fen Bilimleri Enstitüsü Yüksek Lisans Tezi, 38s, Kahramanmaraş.

Karaca M, Güncan A 2009, Yabani Çavdar'ın (Secale cereale L.) bazı biyolojik özellikleri ve Konya ilinde buğday ürününe karışma oranının belirlenmesi, Türkiye III. Bitki Koruma Kongresi (15-18 Temmuz 2009, Van) 268.

Kaymak S, Özdem A, Karahan A, Özercan B, Aksu P, Aydar A, Kodan M, Yılmaz A, Başaran S, Sav Ü, Erdoğan P, Güler Y 2015. Türkiyede Zirai Mücadele Girdilerinin Değerlendirilmesi. https://arastirma. tarim.gov.tr/zmmae/Belgeler/ Sol \%20Menu/ Yay\% C4\%B1nlar/ \%C3\%9Clkemizde\% 20Zirai\%20M \%C3\%BCcadele\%20Girdilerinin\%20De\%C4\%9Ferl endirilmesi.pdf. Erişim tarihi: 30.12.2017.

Kün E 1988. Serin İklim Tahılları. Ankara Üniv. Ziraat Fak. Yayınları No:1032, Ders Kitabı No: 299, Ankara.

Mennan H, Işık D 2003. Buğday Tohumluğunda Bulunan Yabancı Ot Tohumlarının Yoğunlukları ve Bitkiye Dönüşüm Oranlarının Saptanması. Türkiye Herboloji Dergisi, 6 (1): 8-15.

Özer Z, Kadıoğlu İ, Önen H, Tursun N 1998. Herboloji (Yabancı Ot Bilimi) Gaziosmanpaşa Üniversitesi Ziraat Fakültesi Yayınları No:20, Tokat, Kitaplar serisi No:10.

Özer Z, Önen H, Tursun N, Uygur F N 1999. Türkiye'nin Bazı Önemli Yabancı Otları (Tanımları ve Kimyasal Savaşımları). Gaziosmanpaşa Üniv., Ziraat Fak. Yayınları No:38, Tokat, Kitaplar Serisi No:16.

Sirma M, Kadıŏlu İ, Güncan A 1997. Tokat Yöresinde Tohumluk Buğday'da Selektörden Önce ve Sonra Ürüne Karışan Yabancı Ot Tohumlarının ve Yoğunluklarının Belirlenmesi. Türkiye II. Herboloji Kongresi (1-4 Eylül 1997, Ayvalık-İzmir) 279.
Şin B, Kadığlu İ, Kamışlı B 2016. Tokat ilinde buğday ürününe karışan yabancı ot tohumlarının belirlenmesi. Turkish Journal of Weed Science. 19 (2): 28-37.

Tepe I 1998. Van'da buğday ürününe karışan yabancıot tohumlarının yoğunluk ve dağılımları. Türkiye Herboloji Dergisi, 1 (2): 1-13.

Topuz M, Nemli Y 2001. Manyas (Balıkesir) ilçesi hububat tarlalarındaki topraktaki bazı önemli yabancı ot tohumlarının yoğunluklarının tespiti ve topraktaki tohum popülasyonu ile yabancı ot florası arasındaki ilişkilerin belirlenmesi üzerine ön çalışmalar. Türkiye II. Herboloji Kongresi, S. 457. Ayvalık-İzmir.

Topuz M 2007. Marmara Bölgesi Buğday Tarlalarında Yabani Hardal (Sinapis arvensis L.)'in Sulfonylüre Grubu Herbisitlere Karşı Oluşturduğu Dayanıklılık Üzerinde Çalışmalar. Ege Üniversitesi Fen Bilimleri Enstitüsü, Bitki Koruma Ana Bilim Dalı Doktora Tezi, 226 s., İzmir.

Tursun N 1995. Sivas ve Yöresinde Hasat Şekline Bağlı Olarak Buğday Ürününe Karışan Yabancıot Tohumları Üzerinde Araştırmalar. Gaziosmanpaşa Üniversitesi Fen Bilimleri Enstitüsü, Bitki Koruma Ana Bilim Dalı Yüksek Lisans Tezi, 73s, Tokat.

Tursun N, Kantarcı Z, Seyithanoğlu M 2004. Adıyaman ve Gaziantep bölgelerinde buğday ürününe karışan yabancı ot tohumlarının belirlenmesi. Türkiye Herboloji Dergisi 7 (1): 1-12.

Tursun N, Kantarcı Z, Seyithanoğlu M 2006. Kahramanmaraş'ta buğday ürününe karışan yabanc1 ot tohumları belirlenmesi. Kahramanmaraş Sütçü İmam Üniv. Fen ve Mühendislik Dergisi, 9 (2): 110-115.

Türkseven SG 2011. Marmara Bölgesi Buğday Alanlarında Yabani Yulaf (Avena fatua L.) ve Kısır Yabani Yulaf (Avena sterilis L.)'in Herbisitlere Dayanıklılığının Araştırılması. Ege Üniversitesi Fen bilimleri Enstitüsü Bitki Koruma Ana Bilim Dalı Doktora Tezi,117s., İzmir.

USDA 2018. United States Department of Agriculture. Introduced, Invasive, and Noxious Plants. https://plants.usda.gov/java/noxiousDriver Erişim tarihi: 11.12.2018.

Uygur FN, Koch W, Walter H, 1986. Çukurova Bölgesi Buğday-Pamuk Ekim Sistemindeki Önemli Yabancı Otların Tanımı. - PLITS 1986/4 (1), Josef Margraf Verlag, Stuttgart, 169 pp.

Zengin H 1996. Erzurum ve ilçelerinde yazlık buğday ürününe karışan yabancı ot tohumları ve yoğunlukları üzerinde araştırmalar. Atatürk Üniversitesi Ziraat Fakültesi Dergisi, 27 (3): 411422 . 